\title{
乱流モデルを用いた計測融合シミュレーションによる オリフィス流れの可視化
}

\author{
中 尾 光 博* ・川嶋 健 嗣** 香 川 利 春**
}

Visualization of Orifice Flow with Measurement-integrated Simulation Using a Turbulent Model

\author{
Mitsuhiro NaKaO*, Kenji KaWAShima** and Toshiharu KagaWA**
}

\begin{abstract}
Measurement-integrated (MI) simulation is a numerical simulation in which experimental results are fed back to the simulation. The calculated values become closer to the experimental values. In this paper, MI simulation using a standard $k^{-} \varepsilon$ model is proposed and applied it to steady airflows passing an orifice plate in a pipeline. The upstream corner tap pressure in simulation is compensated by using proportional controller or proportional ${ }^{-}$ integral controller. The signal is fed back to the axial velocity control volume in vena contract. The effectiveness of the method was evaluated compared with the experimental results at downstream of orifice. The calculation time of proposed MI simulation is significantly reduced compared with ordinary simulation analysis.
\end{abstract}

Key Word : flow measurement, turbulent flow, measurement-integrated simulation, feedback, orifice

\section{1. はじめに}

プラントやパイプラインなどにおける流れの状態を可視化 することは, 安全な操業や故障診断の上で非常に重要であ る.

流れ場の状態を解析するための方法は，大きく 2 つに分類 できる. 1 つは直接状態量を計測する方法であり，もう 1 つ は流れの支配方程式を数值計算によって解くことで状態量を 推定する方法 Computational Fluid Dynamics (CFD)であ る1). 計測には流速計や圧力計のような計測機器を用いる方 法や Particle Imaging Velocimetry (PIV)のような画像処理 による方法がある2). 計測機器による方法は, 計測点におけ る状態量は正確に計測できるが，可視化には適さない．画像 処理による方法は可視化には適するが，原理上適用できる流 れ場に制限がある。一方 CFD は可視化に適するが，実際の 流れに近い状態量を算出するためには, 適切な初期条件や境 界条件の設定や, 乱流の場合には実現象を再現できるモデル や計算格子を使う必要があり，困難を伴う。

そこで計測と CFD を融合させた計測融合シミュレーショ ン(Measurement-Integrated Simulation; MI シミュレー

* 東京工業大学大学院 横浜市緑区長津田町 4259 R2-46

** 東京工業大学精密工学研究所 横浜市緑区長津田町 4259 R2-46

* Graduated school, Tokyo Institute of Technology, 4259 R2-46 Nagatsuta-cho, Midori-ku, Yokohama

** Precision and Intelligence Lab., Tokyo Institute of Technology, 4259 R2-46 Nagatsuta-cho, Midori-ku, Yokohama (Received September 8, 2009)
ション)が提案されている ${ }^{3)}$. Fig. 1 に概念図を示すが，こ の方法は CFD に計測值をフィードバックすることで, 実際 の流れに近い解を得るものである. 簡単なモデルを用いて も, 十分な精度をもつ解が得られるため, 比較的短時間の計 算で状態量を得ることが可能となり，流れ場のオブザーバと しての活用が期待されている. 先行研究では, 層流域の四角 柱後流のカルマン渦(4) や複雑な血流流れ ${ }^{5}$ において検討がな され, 有効性が確認されているが, 乱流モデルを用いた乱流 場の解析に適用した例はない.

著者らは計算時間の短縮に注目して, MI シミュレーショ ンを用いたプラント配管などの流れ場のモニタリングシステ ム構築を目指している. 乱流域におけるオリフィスの非定常 流れを対象とした検討では, 流速計測值のフィードバックを 行なうことで, 粗い格子を用いても流速は計測值とほぼ一致 することを確認した ${ }^{6)}$. しかし, 圧力場の精度が不十分であ り, 計測点が 7 点も必要であった。この主原因は乱流場を層 流モデルで解いていたためにモデル誤差が大きかったためで

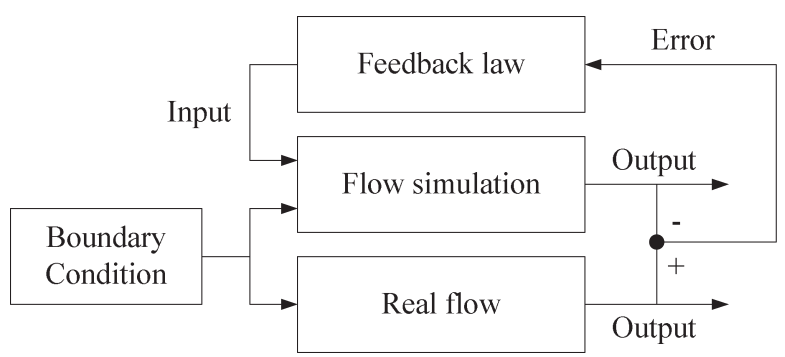

Fig. 1 MI simulation 
ある，実用性を考慮すると，流速よりも計測が簡易な壁面圧 力を用いたフィードバックが望ましい.

そこで本報では，壁面圧力を用いたフィードバックを可能 とするために，乱流場の解析のために乱流モデルとして高レ

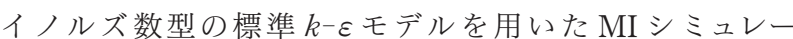
ションを提案し, 定流量の場合について検討を行なう。コー ナータップの上流側圧力 1 点をフィードバックに用いる計測 点とし，縮流部流速の $\mathrm{P}$ 制御および PI 制御により制御する ことを考案した。空気を作動流体として，オリフィス下流の 管中心の流速および圧力，壁面圧力，計算時間について比較 を行なう．提案手法と計測值，同様のフィードバックを用い た層流モデル MI シミュレーションおよび市販ソフトを用い た CFD 解析との比較を行ない，有効性を確認する。

記号表

$f \quad$ フィードバック信号

e 偏差

$K_{1} \mathrm{P}$ 制御の比例ゲイン

$[-]$

$K_{2} \quad \mathrm{PI}$ 制御の比例ゲイン

$[-]$

$K_{3}$ 積分ゲイン

$[-]$

$\alpha$ 縮流係数

$[-]$

$\beta$ オリフィス絞り比

$[-]$

$Q$ 体積流量

$U$ 軸方向流速

$U_{0}$ 入口に扔ける軸方向平均流速

$\left[\mathrm{m}^{3} / \mathrm{s}\right]$

$V$ 半径方向流速

$[\mathrm{m} / \mathrm{s}]$

$[\mathrm{m} / \mathrm{s}]$

$P$ 圧力

$[\mathrm{m} / \mathrm{s}]$

$X$ 軸方向座標

$[\mathrm{Pa}]$

$R$ 半径方向座標

[m]

$R_{0}$ 配管半径

$[\mathrm{m}]$

$\rho$ 密度

$\mu \quad$ 粘性係数

[m]

$\left[\mathrm{kg} / \mathrm{m}^{3}\right]$

$[\mathrm{Pa} \cdot \mathrm{s}]$

$[-]$

$\operatorname{Re}$ レイノルズ数 $R e=2 \rho U_{0} R_{0} / \mu$

$x$ 無次元軸方向座標 $x=X / R_{0}$

$[-]$

$r$ 無次元半径方向座標 $r=R / R_{0}$

$[-]$

$u$ 無次元軸方向流速 $u=U / U_{0}$

$[-]$

$v$ 無次元半径方向流速 $v=V / U_{0}$

$[-]$

$p$ 無次元圧力 $p=P /\left(\rho U_{0}^{2}\right)$

$[-]$

$k$ 無次元乱流エネルギー $k=\widehat{k} / U_{0}^{2}$

$[-]$

$\varepsilon$ 無次元散逸率 $\varepsilon=\widehat{\varepsilon} R_{0} / U_{0}^{3}$

$[-]$

$\nu_{t} \quad$ 無次元乱流動粘性係数 $\nu_{t}=\widehat{\nu}_{t} /\left(U_{0} R_{0}\right) \quad[-]$ 添え字

$\begin{array}{llll}* & \text { 推定量 } & \text { - 有次元量 } \\ , & \text { 修正量 } & \text { exp } & \text { 計測値 } \\ \operatorname{sim} & \text { 計算值 } & & \end{array}$

\section{2. 計算方法}

\section{1 対象とする流れ場}

対象とする流れ場の概略と計算格子を Fig. 2 に示す。内 径 $52 \mathrm{~mm}$ の配管を対象とし, 流入口から 1,100 mm の位置

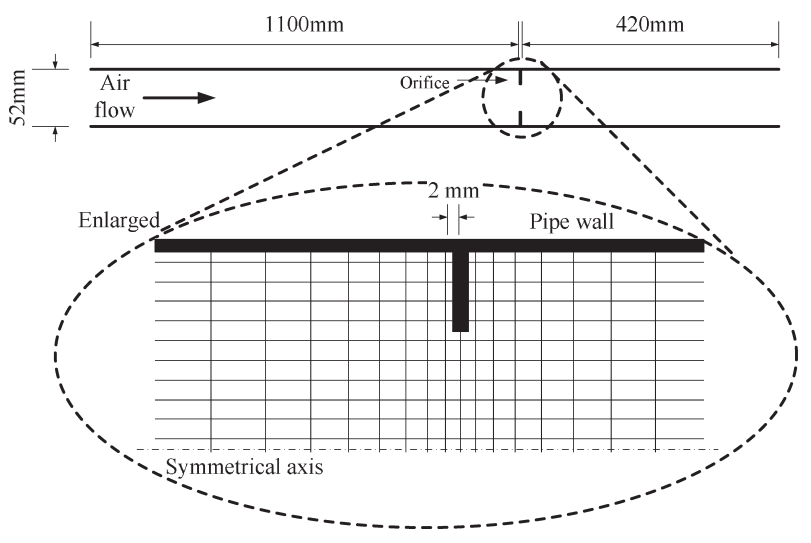

Fig. 2 Flow field and computational grid

に絞り比 0.6 のオリフィスを設置し, オリフィス下流 420 $\mathrm{mm}$ で大気開放として空気を流す。

乱流モデルを用いてオリフィス流れを解析した例として は, Erdal らの計算格子やスキームの影響についての研究7) や Ganiev らの乱流モデルによる差異についての研究8) があ る. Erdal らは，オリフィス上流の圧力の計算值を計測值と ほぼ同じ值に収束させるには，オリフィス部に非常に細かい 計算格子が必要としている7). Ganiev らは十分細かい格子 を用いれば，流れの詳細なようすはモデルに依存するもの の, 縮流の再現についてはモデル間の差が小さいと結論づけ ている ${ }^{8)}$.

実際のオリフィスは絞り部分で粘性の影響を小さくするた めにエッジが立っている。通常の数值計算においては，エッ ジ周りには多数の格子を配置しなければならないが, 本研究 ではフィードバック効果に期待して，簡単のために絞りとし て扱い，計算時間短縮のために格子を粗くした。

計算格子は振動解を抑えるためにスタッガード格子を用い た。効率的な計算を行なうために，流れの非線型性の強い才 リフィス周りに最も細かい格子を適用し, 周囲にいくにつれ て格子を粗くする. Spencer らによると，隣接する格子間に おける格子幅の比は 1.2 以下が望ましいとしている ${ }^{9}$. そこ でオリフィス部の軸方向格子幅は $2 \mathrm{~mm}$ とし，その上流およ び下流は格子幅を 1.2 倍ずつ増加させている. 半径方向格子 幅は $2.6 \mathrm{~mm}$ とした。オリフィス部の格子幅は, Erdal らの 指摘する格子幅の㧍よそ 200 倍であり, 非常に粗い. 本研究 では Fig. 2 に示す管路全体をおよそ500 格子に分割してい る.

\section{2 支配方程式}

乱流は非常に複雑な現象であるが, 実用上は主流成分がわ かれば十分なことが多い。そこで本研究では, 乱流の詳細な 変動を追うことはせず，RANS 型の乱流モデルを用いる. その中でも, 最も計算負荷の軽い高レイノルズ数型の標準

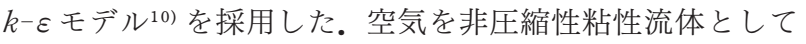
扱い，流れ場は 2 次元軸対象円筒座標系として扱った.

無次元化した運動方程式と連続の式は以下のようになる。 (1) 式の $f$ はフィードバック信号を意味する. 


$$
\begin{aligned}
u \frac{\partial u}{\partial x} & +v \frac{1}{r} \frac{\partial r u}{\partial r}=-\frac{\partial p}{\partial x}+\left(\frac{1}{R e}+\nu_{t}\right)\left\{\frac{\partial^{2} u}{\partial x^{2}}\right. \\
& \left.+\frac{1}{r} \frac{\partial}{\partial r}\left(r \frac{\partial u}{\partial r}\right)+\frac{\partial^{2} u}{\partial x^{2}}+\frac{1}{r} \frac{\partial}{\partial r}\left(r \frac{\partial v}{\partial x}\right)\right\}+f \\
u \frac{\partial v}{\partial x} & +v \frac{1}{r} \frac{\partial r v}{\partial r}=-\frac{\partial p}{\partial r}+\left(\frac{1}{R e}+\nu_{t}\right)\left\{\frac{\partial^{2} v}{\partial x^{2}}\right. \\
& \left.+\frac{1}{r} \frac{\partial}{\partial r}\left(r \frac{\partial v}{\partial r}\right)+\frac{\partial}{\partial x}\left(\frac{\partial u}{\partial r}\right)+\frac{1}{r} \frac{\partial}{\partial r}\left(r \frac{\partial v}{\partial r}\right)-2 \frac{v}{r^{2}}\right\}
\end{aligned}
$$

$$
\frac{\partial u}{\partial x}+\frac{1}{r} \frac{\partial(r v)}{\partial r}=0
$$

乱流エネルギー $k$ および散逸率 $\varepsilon$ の輸送方程式は以下に示 される。

$$
\begin{gathered}
u \frac{\partial k}{\partial x}+v \frac{1}{r} \frac{\partial r k}{\partial r}=\left(\frac{1}{R e}+\frac{\nu_{t}}{\sigma_{k}}\right)\left\{\frac{\partial}{\partial x}\left(\frac{\partial k}{\partial x}\right)\right. \\
\left.+\frac{1}{r} \frac{\partial}{\partial r}\left(r \frac{\partial k}{\partial r}\right)\right\}+G-\varepsilon \\
u \frac{\partial \varepsilon}{\partial x}+v \frac{1}{r} \frac{\partial r \varepsilon}{\partial r}=\left(\frac{1}{R e}+\frac{\nu_{t}}{\sigma_{\varepsilon}}\right)\left\{\frac{\partial}{\partial x}\left(\frac{\partial \varepsilon}{\partial x}\right)\right. \\
\left.+\frac{1}{r} \frac{\partial}{\partial r}\left(r \frac{\partial \varepsilon}{\partial r}\right)\right\}+C_{1} G \frac{\varepsilon}{k}-C_{2} \frac{\varepsilon^{2}}{k} \\
G=\nu_{t}
\end{gathered}
$$

計算には以下のパラメータを用いる.

$$
\sigma_{k}=1.0 \sigma_{\varepsilon}=1.3 C_{1}=1.44 C_{2}=1.92 C_{\mu}=0.09
$$

また，壁面に接する格子内の流れ場の計算には，壁法則を適 用した ${ }^{7)}$ 厳密にはオリフィス近傍の格子は壁法則の適用が 相応しくないが，フィードバック効果に期待して適用した。

これらの式を有限体積法により離散化し, SIMPLE 法で 解いた。計算の安定性を考慮して, 対流項には 1 次精度風上 差分を, 粘性項には 2 次精度中心差分を用い, ハイブリッド 法で離散化した ${ }^{11)}$. 行列方程式の解法には, 三重対角化行列 アルゴリズム(Tri-Diagonal Matrix Algorithm)と線順法 (Line by Line Method)を組み合わせて用いた。温度変化は 無視し，291 K の一定温度とした。密度は $1.21 \mathrm{~kg} / \mathrm{m}^{3}$, 粘 度は $1.8 \times 10^{-5} \mathrm{~m}^{2} / \mathrm{s}$ とした。 入口境界として流量計により 計測した流量に相当する一様流速を与え, 出口境界として流 速勾配 0 と圧力 0 を与えた。緩和係数は乱流モデルを用いた 計算では 0.3 , 層流モデルを用いた計算では 0.2 とし, 計算 の収束判定は, 圧力修正量の絶対値の総和が $10^{-6}$ 以下とし た.

比較のために市販の CFDソフトウェア (Cradle 社製 SCRYU/Tetra Ver. 7)を用いた計算を行なった。計算条件 としては, 支配方程式の離散化に 2 次の MUSCL 法 ${ }^{12)}$, ソ ルバーには SIMPLEC 法1), 緩和係数はベクトル量について は 0.3 , スカラー量については 0.4 , 収束条件には流速の変 動值が $10^{-6}$ 以下を用いた。計算格子数はおよそ 29,000 であ る.

\section{3 フィードバック則}

管路壁面の圧力計測は流速計測と比較すると安価かつ高精 度に行なうことができるため, 管路壁面の圧力計測值を用い たフィードバック方法が構築できれば有用である。そこで,

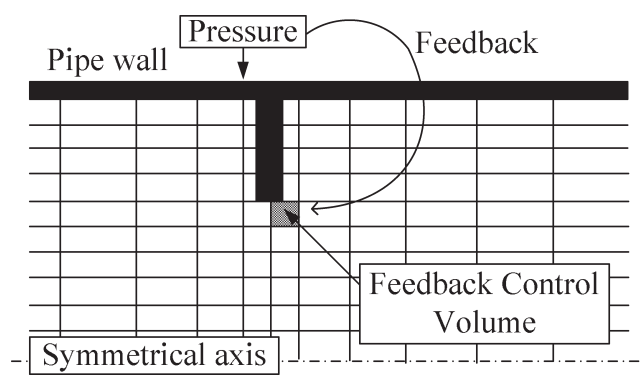

Fig. 3 Axial velocity control volumes and the feedback point

管路壁面の圧力計測值を用いたフィードバック方法を提案す る.

オリフィスの通過流量と前後差圧の関係は以下の式で表わ される13).

$$
Q=\frac{\alpha}{\sqrt{1-\beta^{4}}} \pi\left(R_{0} \beta\right)^{2} \sqrt{\frac{2 \Delta P}{\rho}}
$$

CFD では流入流量は計測值によって与えられ, SIMPLE 法による解法では質量保存則が満たされる。したがって, オ リフィスの通過流量 $Q$ は実験と CFD で等しい. しかし, Erdal らの研究によって, オリフィス近傍の計算格子が粗い ほど，上流圧やオリフィスによる圧力損失を低く見積もるこ とがわかっている7)。これは(6)式に基づいて考察すると, 縮流係数を大きく見積もっているためである.

そこでFig. 3 に示すようにコーナータップの上流側圧力 の圧力計測値を数値計算にフィードバックする. 圧力は無次 元化して組み込まれ，偏差は（７）式のように記述される。

$$
e=\frac{P_{\exp }}{\rho U_{0}^{2}}-p_{\mathrm{sim}}
$$

フィードバック方法としては P 制御と PI 制御について検 討する. P制御では，フィードバック信号は 1 つ前の計算 ループに拈ける偏差にゲインをかけた式で表わされる。な お，ゲイン 0 は通常のシミュレーションである.

$$
f=-K_{1} e
$$

PI 制御では偏差に加えて, 計算の収束過程のすべての偏 差の和が組み込まれる。

$$
f=-K_{2}\left(e+\frac{\sum e}{K_{3}}\right)
$$

この信号を Fig. 3 に示すオリフィス部の軸方向流速コント ロールボリューム 1 つにフィードバックする。この位置の流 速は縮流のためにかなり小さな值をもつ. 上流圧力が低く計 算されるときは，この流速を大きく見積もっていることか ら，フィードバックによって流速を小さくする方向に修正す る.

\section{4 フィードバック方法}

Fig. 4 に計算のフローチャートを示す. 通常の SIMPLE 法の計算の収束過程において，1つ前の計算ループの圧力計 算值と計測值の偏差からフィードバック信号を作り出し, 流 速の推定值の計算段階にフィードバックする.

計算の初期段階からフィードバックを行なうとゲインを大 きくすることができない. そこで, ある程度計算が収束して 


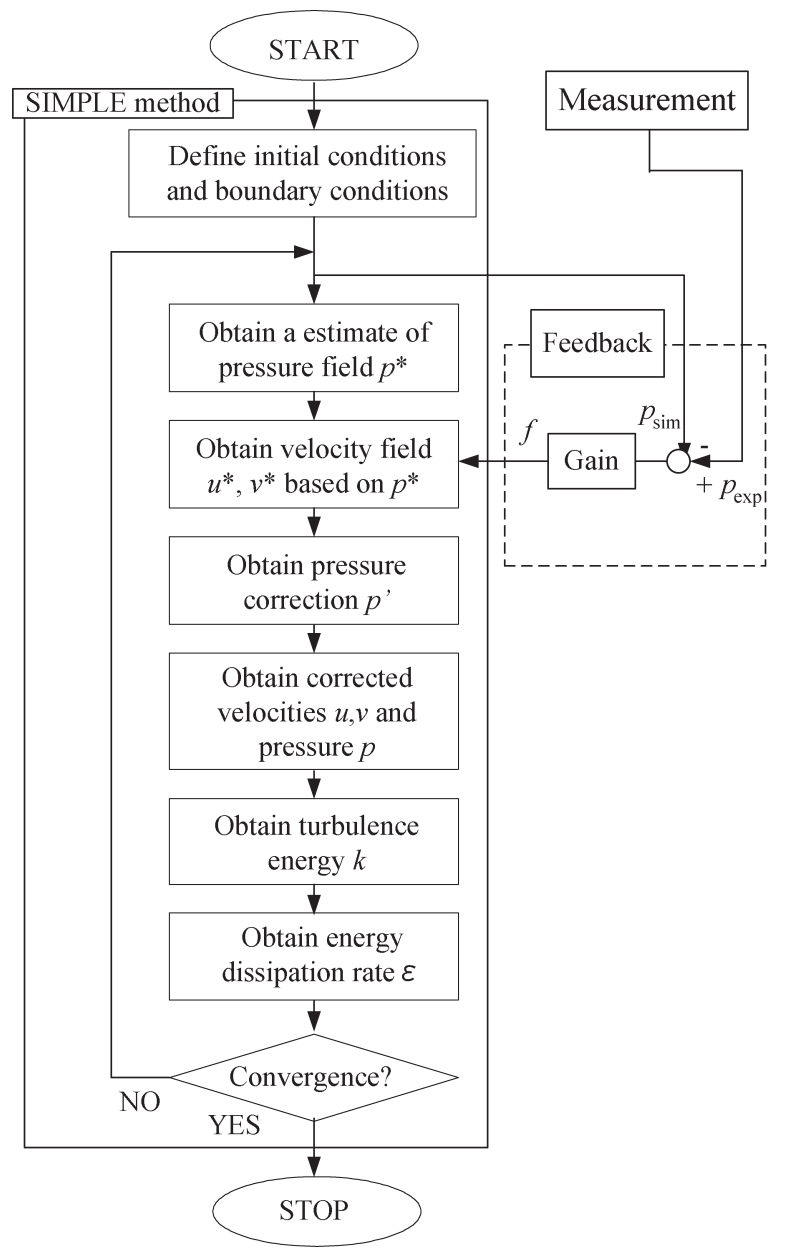

Fig. 4 Flow chart of the calculation algorithm

からフィードバック項を加える．圧力修正量の絶対值の総和 が $10^{-6}$ 以下を収束判定の基準としたことから，フィード バックは $10^{-2}$ 以下となったときから開始した。

\section{3. 実験方法}

Fig. 5 に実験装置の概略を示す。供給圧を $0.6 \mathrm{MPa}$ (gauge)に設定し, 脈動低減のために $0.1 \mathrm{~m}^{3}$ のバッファー タンクを設置した。流量計測用にあらかじめ不確かさ $0.3 \%$ 以内の乾式流量計 SHINAGAWA DS65-A で校正した高速 応答層流型流量計 (QFS) を用いた ${ }^{14)}$. 対象流れ場を QFS 下 流に設置した。オリフィス板上流直管部の長さが $30 R_{0}$ 以上 であれば，直管による付加不確かさは $0.5 \%$ である ${ }^{13)}$. QFS からオリフィス板までの長さはおよそ $42 R_{0}$ であり, 十分長 いので発達したオリフィス流れとみなせる。

また，Fig. 6 に示すように標準ピトー管の静圧孔を用いて 管中心の静圧，全圧および流速を計測した。用いたピトー管 の径は $1.8 \mathrm{~mm}$, 静圧孔の孔径は $1 \mathrm{~mm}$, 孔数は 3 つ, 全圧 孔と静圧孔の間の長さは $18 \mathrm{~mm}$ である. 空気の温度は出口 に設置したガラス製温度計により計測した。計測中の室温は $291 \pm 2 \mathrm{~K}$ の範囲内であったことから，密度変化の影響は 1\%未満であり，一定として扱った。

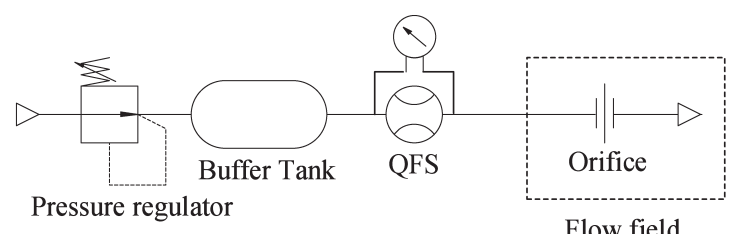

Fig. 5 Experimental apparatus

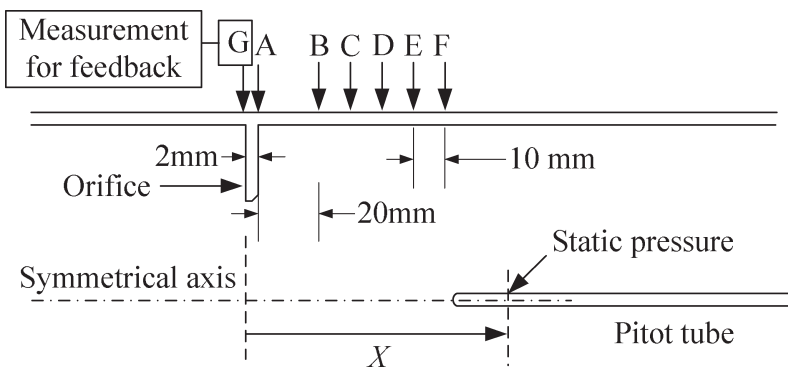

Fig. 6 Measurement points

管中心の静圧については，オリフィス中心を $X$ 座標の原 点とし， $5 \mathrm{~mm}$ 刻みで $200 \mathrm{~mm}$ まで計測した。壁面圧力につ いては，A点から $\mathrm{G}$ 点までの 7 点で計測した， $\mathrm{A}$ 点はオリ フィス板直後, $\mathrm{G}$ 点はオリフィス板直前であり, $\mathrm{AB}$ 間の距 離は $20 \mathrm{~mm}$, それ以降は $10 \mathrm{~mm}$ となっている. $\mathrm{G}$ 点のみが フィードバックに用いられる計測点である.

壁面およびピトー管の圧力計測には微差圧計 (長野計器 KL17)の片側を大気開放として用いた。出力值はサンプリン グ間隔 $400 \mu \mathrm{S}$ で $\mathrm{AD}$ ボードを介してコンピュータに取り込 まれた。それぞれの計測点において 10 秒間ずつ計測し，そ の平均値を計測値とした。流入流量は $8.2 \times 10^{-3}$ または $16.5 \times 10^{-3} \mathrm{~m}^{3} / \mathrm{s}$ とした. 配管直径を基準としたレイノルズ 数はそれぞれ約 $13,000 ， 27,000$ となり，乱流である。

\section{4. 結果と考察}

\section{1 フィードバックゲインの検討}

$\mathrm{P}$ 制御または PI 制御を用いた乱流モデルによる MI シ ミュレーション(それぞれグラフ中では MI P, MI PI と記 す)の, G 点における圧力計算值の収束のようすを Fig. 7 に 示す。横軸は計算収束過程における計算ループ数であり, 縦 軸は $\mathrm{G}$ 点の圧力計算值である. 流入流量 $8.2 \times 10^{-3} \mathrm{~m}^{3} / \mathrm{s}$ に

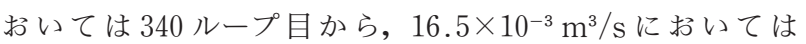
435 ループ目から制御が始まっていた。

ゲインは試行錯誤的に決定し, PI 制御においては， $K_{2}=$ $10, K_{3}=20$ とした. PI 制御では一般に定常偏差は残らな い. 今回の条件においても定常偏差が残っていなかった。

$\mathrm{P}$ 制御ではゲインが大きいほど定常偏差は減少するが，ゲ インを大きくしすぎると発散してしまう。ゲインを 1 刻みで 変化させた場合, 流入流量 $8.2 \times 10^{-3} \mathrm{~m}^{3} / \mathrm{s}$ においては $K_{1}=$ $38,16.5 \times 10^{-3} \mathrm{~m}^{3} / \mathrm{s}$ においては $K_{1}=39$ が安定に計算できる 上限であった。しかし，上限のゲインにおいても $\mathrm{P}$ 制御の 場合の収束值には定常偏差が残っていた。以下の比較では, 


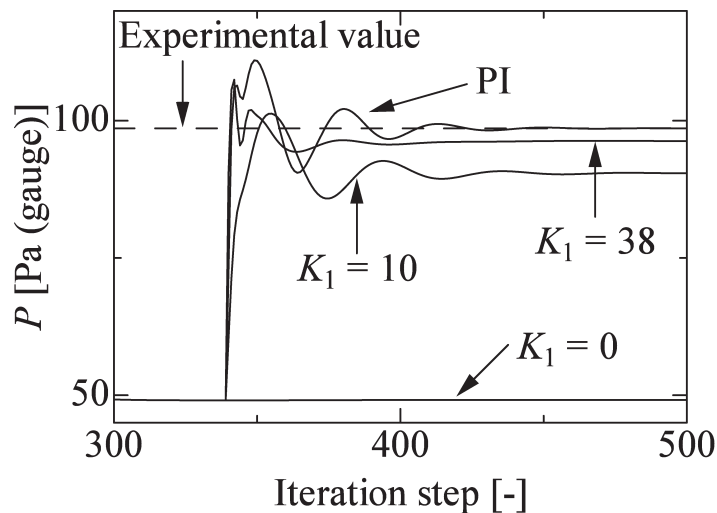

(a) $Q=8.2 \times 10^{-3}\left[\mathrm{~m}^{3} / \mathrm{s}\right]$

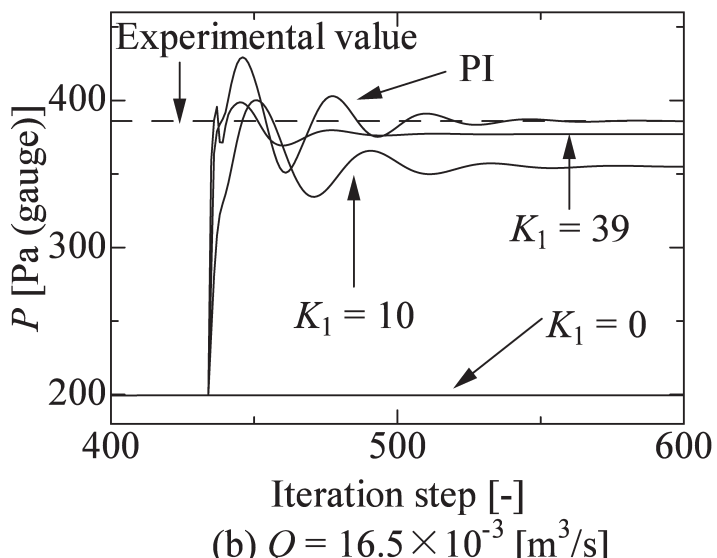

Fig. 7 Pressure response results of MI simulation with turbulent model at feedback point $G$

ゲインは上記の值を用いた。PI 制御を用いた層流モデルに よる MI シミュレーションでは, $K_{2}=0.5, K_{3}=20$ とした。

\section{2 実験との比較}

配管中心流速，配管中心圧力および壁面圧力について，計 測值と MI シミュレーションと同じ計算格子を用いたフィー ドバックなしの CFD, P制御および PI制御による MI シ ミュレーション，壁面圧力フィードバックを用いた層流モデ ルによる MI シミュレーションおよび市販ソフトを用いた $\mathrm{CFD}$ 解析の比較を行なった。 ただし，層流モデルを用いた 計算では流入流量 $16.5 \times 10^{-3} \mathrm{~m}^{3} / \mathrm{s}$ において計算が収束しな かった.

層流モデルを用いた計算では, 剥離流れも層流場として計 算してしまうために再付着長さを長く見積もってしまい，配 管の出口でも剝離流れとして計算していたために計算が不安 定になったと考えられる. 前報6)では， 7 点の流速フィード バックを用いたことで実現象に近い流速分布を与えていたた めに収束したが，今回の壁面圧力 1 点を用いたフィードバッ クでは不安定となることがわかった。

Fig. 8 に配管中心流速の結果を示す.フィードバックなし の場合は実験值と計算值の誤差が非常に大きい. MI シミュ レーションの結果はオリフィス下流 $20 \mathrm{~mm}$ 程度までは計測 值と概ね一致し，その後の領域でも誤差はあるものの， フィードバックなしの結果と比較すると大きく改善され，市

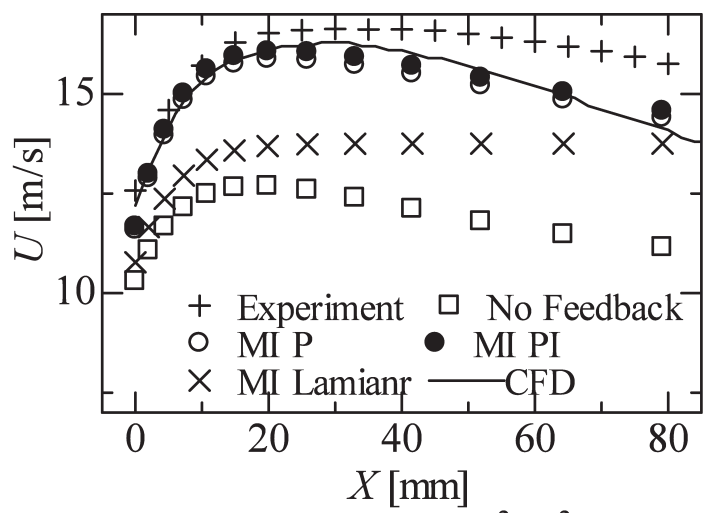

(a) $Q=8.2 \times 10^{-3}\left[\mathrm{~m}^{3} / \mathrm{s}\right]$

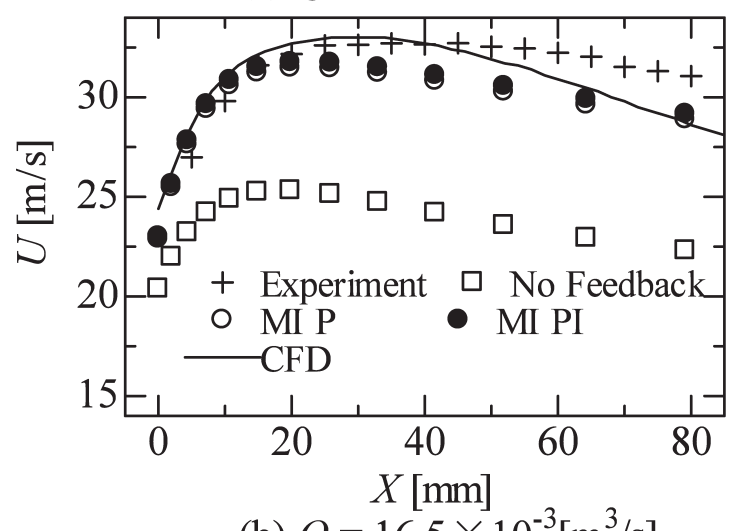

(b) $Q=16.5 \times 10^{-3}\left[\mathrm{~m}^{3} / \mathrm{s}\right]$

Fig. 8 Comparison of axial velocities on the centerline

販ソフトを用いた CFD 解析の結果と非常に近い。一方, 層 流モデルを用いた MI シミュレーションでは, 乱流モデルを 用いた MI シミュレーションと比較すると誤差が大きい。

Fig. 9 に配管中心圧力の結果を示す.この領域において は，縮流のために急激な圧力降下がみられる，市販ソフトを 用いた CFD 解析の結果は圧力回復を早めに見積もっている ものの，オリフィス下流 $30 \mathrm{~mm}$ 付近の最も圧力が低下する 領域に扔いて圧力降下のようすをよく表わしている. Erdal らの研究でも同様の結果であったので7)，これは用いた乱流 モデルの限界であると考えられる。乱流モデルを用いた MI シミュレーションではフィードバックによって, 計算值が市 販ソフトを用いた CFD 解析に近づいていることがわかる. しかし, 層流モデルを用いた計算では圧力降下のようすは再 現できていない.

Fig. 10 に壁面圧力の比較を示す.配管中心圧力の結果と 同様の傾向がみられ，乱流モデルを用いた MI シミュレー ションでは，すべての領域で改善がみられるが，圧力回復を 早く見積もっている.いずれの結果でも, 定常偏差の残る $\mathrm{P}$ 制御よりも定常偏差の残らない PI 制御のほうがわずかなが ら計測值に近い。

\section{3 可視化}

Fig. 11 に流量 $16.5 \times 10^{-3} \mathrm{~m}^{3} / \mathrm{s}$ の場合の, オリフィス直 後から下流 $200 \mathrm{~mm}$ までの軸方向流速抢よび圧力分布の可視 化結果を示す，格子点間の值は線形補間により計算した值を 


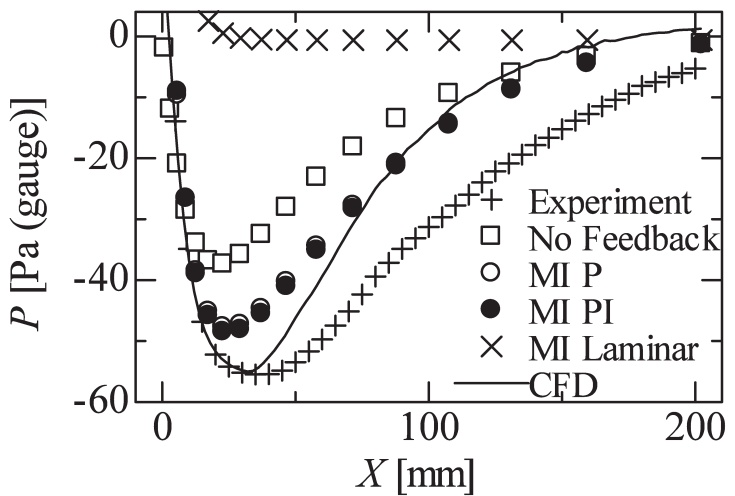

(a) $Q=8.2 \times 10^{-3}\left[\mathrm{~m}^{3} / \mathrm{s}\right]$

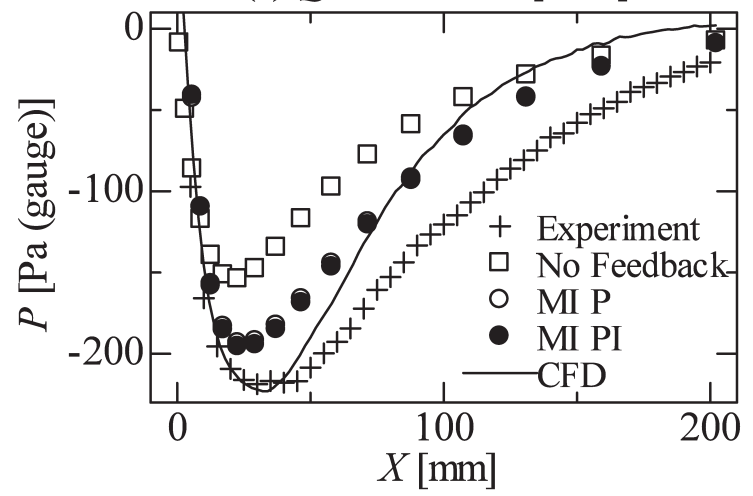

(b) $Q=16.5 \times 10^{-3}\left[\mathrm{~m}^{3} / \mathrm{s}\right]$

Fig. 9 Comparison of pressures on the centerline

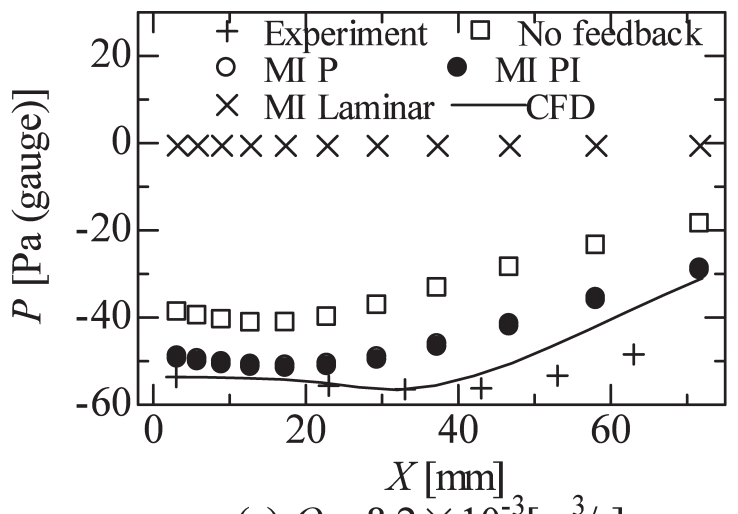

(a) $Q=8.2 \times 10^{-3}\left[\mathrm{~m}^{3} / \mathrm{s}\right]$

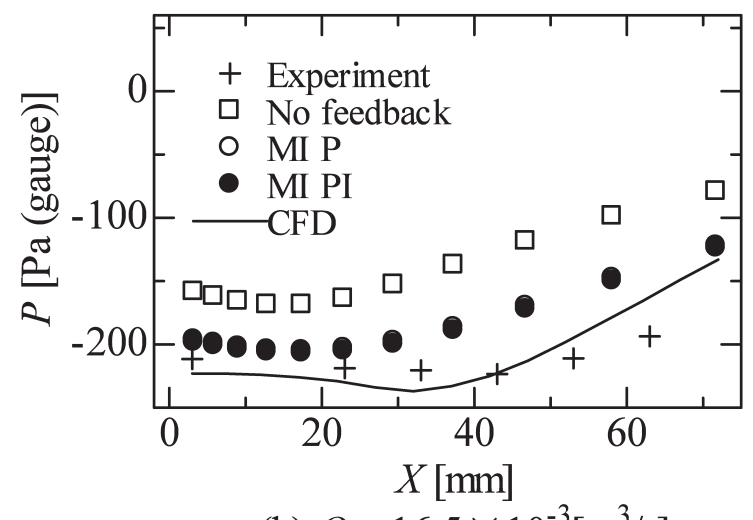

(b) $Q=16.5 \times 10^{-3}\left[\mathrm{~m}^{3} / \mathrm{s}\right]$

Fig. 10 Comparison of wall pressures

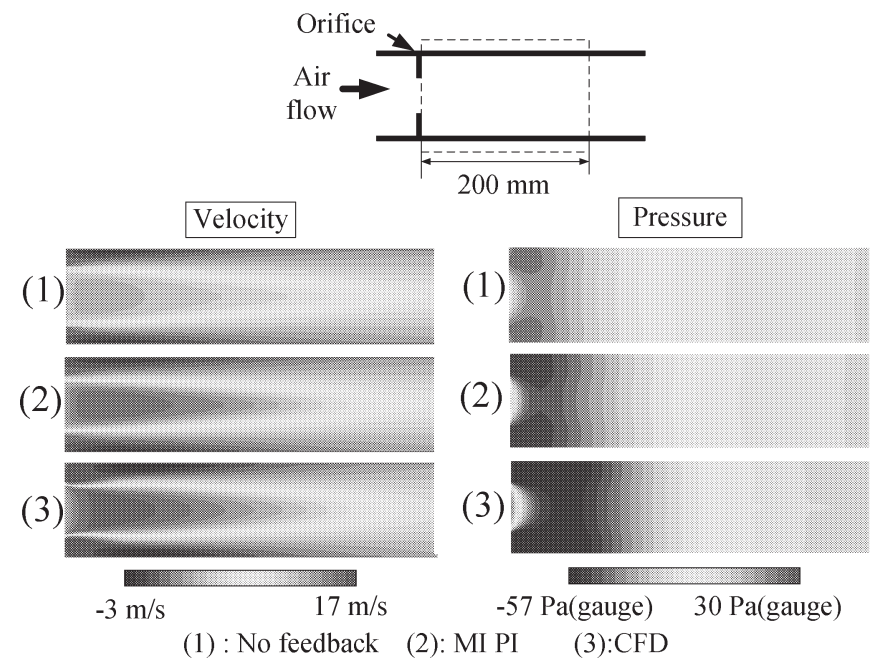

Fig. 11 Visualization results of axial velocity and pressure distributions downstream of an orifice

Table 1 Comparison of calculation times

\begin{tabular}{|c|c|c|}
\hline$Q\left[\times 10^{-3} \mathrm{~m}^{3} / \mathrm{s}\right]$ & 8.2 & 16.5 \\
\hline No feedback & $2.9 \mathrm{~s}$ & $3.3 \mathrm{~s}$ \\
\hline MI P & $3.9 \mathrm{~s}$ & $4.2 \mathrm{~s}$ \\
\hline MI PI & $4.0 \mathrm{~s}$ & $4.3 \mathrm{~s}$ \\
\hline MI Laminar & $9.4 \mathrm{~s}$ & Not converged \\
\hline CFD & 2 hours & 2 hours \\
\hline
\end{tabular}

用いた。乱流モデルを用いた MI シミュレーションでは，流 速，圧力分布ともにフィードバック効果が全体に及び, フィードバックなしの CFD と比較すると市販ソフトを用い た CFD 解析の結果に近づいていることが確認できた.

\section{4 計算時間の比較}

Table 1 にフィードバックなしの CFD, 提案した乱流モ デルを用いた MI シミュレーション，層流モデルを用いた

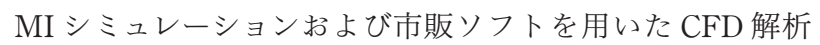
による計算時間の比較を示す。計算には CPU : Core2Duo $\mathrm{E} 6600$, メモリ：2 GBの DOS/Vパーソナルコンピュータ を用いた。

$\mathrm{P}$ 制御， PI 制御ともにフィードバックなしの CFD と比較 して時間がかかっているが，30\%程度の増加である。また， $\mathrm{P}$ 制御と PI 制御の計算時間はほぼ同じである。

層流場の計算は一般に乱流場の計算よりも短時間である が，今回の条件では計算が不安定なため, 計算時間は流入流 量 $8.2 \times 10^{-3} \mathrm{~m}^{3} / \mathrm{s}$ の場合で乱流モデルを用いた MI シミュ レーションの 2 倍以上であった.

一方市販ソフトを用いた CFD 解析では計測值と概ね等し いオリフィス上流圧を得るために非常に細かい計算格子を用 いなければならず，およそ 2 時間の計算時間が必要であっ た。市販ソフトを用いた CFD 解析に必要な計算時間は, 乱 流モデルを用いた MI シミュレーションの計算時間の 1500 倍以上であり, 計算時間の面からも, 本手法はきわめて有効 
であることがわかった。

\section{5. ま と め}

本研究では壁面圧力を用いたフィードバックを可能とする

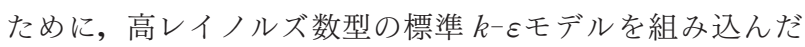

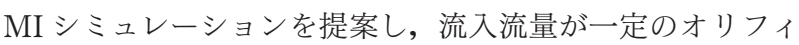
ス流れに適用した。はじめに，実用性を考慮してコーナー タップの上流側圧力 1 点をフィードバックに用いる計測点と し，縮流部流速を $\mathrm{P}$ 制御および $\mathrm{PI}$ 制御により制御する手法 を考案した。

つぎに空気を作動流体として用い，提案した MI シミュ レーションを試行し，考案したフィードバックによって上流 圧の計算值が制御できることを確認した。特にPI 制御では 定常偏差が残らないことを確認した。

さらにオリフィス下流において, 提案した手法と計測值, フィードバックなしの粗い格子を用いた CFD, 層流モデル を用いた MI シミュレーションおよび市販ソフトを用いた $\mathrm{CFD}$ 解析との比較を行なった。 圧力回復を早く見積もって いるが，提案した手法によって管中心流速，管中心圧力，壁 面圧力の計算值が計測值に近づき，市販ソフトを用いた CFD 解析に非常に近い結果が得られることが確認できた。 可視化の結果，フィードバックの効果は部分的にではなく, オリフィス下流全体に及んでいることが明らかとなった。壁 面圧力の計測は安価かつ高精度に行なうことができるため, 提案手法は非常に有用であると考えられる。

最後に計算時間の比較を行ない, 提案手法では市販ソフト を用いた CFD 解析の結果と比較し著しく計算時間が短いこ とを明らかにした。

\section{参 考 文 献}

1) J.H. Ferziger and M. Peric: Computational Methods for Fluid Dynamics, 2nd ed., Springer-Verlag, Tokyo (2003)

2) 可視化情報学会：PIV ハンドブック, 森北出版 (2005)

3) T. Hayase and S. Hayashi : State Estimator of Flow as an Integrated Computational Method with the Feedback of Online Experimental Measurement, Trans. ASME, J. of Fluids Eng., 119-4, 814/822 (1997)

4) K. Nisugi, T. Hayase and A. Shirai : Fundamental Study of Hybrid Wind Tunnel Integrating Numerical Simulation and Experiment in Analysis of Flow Field, JSME International Journal, Series B, 47-3, 593/604 (2004)

5) K. Funamoto, T. Hayase, A. Shirai, Y. Saijo and T. Yamabe: Fundamental Study of Ultrasonic-Measurement-Integrated Simulation of Real Blood Flow in the Aorta, Annals of Biomedical Engineering, 33-4, 415/428 (2005)

6) 井上, 川嶋, 舩木, 香川：計測融合シミュレーションを用いた 非定常流れ場のモニタリング, 計測自動制御学会論文集, 42-7, 837/843 (2006)
7) A. Erdal and H.I. Anderson: Numerical Aspects of Flow Computation Through Orifices, Flow Meas. Instrum., 8-1, 27/37 (1997)

8) R.I. Ganiev, N.A. Nikolaev, V.A. Fafurin, A.N. Sabirzyanov and V.B. Yavkin: Choice of a Turbulence Grid and Model to Calculate the Discharge Coefficient of the Standard Orifice Plate, Russian Aeronautics, 51-4, 377/381 (2008)

9) E.A. Spencer, M.V. Heitor and I.P. Castro : Inter-comparison of measurements and computations of flow through a contraction and a diffuser, Flow Meas. Instrum., 6-1, 3/14 (1995)

10) W.P. Jones and B.E. Launder: The Prediction of Laminarization with a Two-Equation Model of Turbulence, Int. J. Heat Mass Transfer, 15, 301/314 (1972)

11) S.V. Patankar: Numerical Heat Transfer and Fluid, Flow, McGraw-Hill (1980)

12) B. Leer: Towards the Ultimate Conservative Difference Scheme, J. Comp. Phys., 135, 229/248 (1997)

13）JIS Z8762-2：円形管路の絞り機構による流量測定方法一第 2 部：オリフィス板, 日本規格協会 (2007)

14）舩木, 川嶋, 香川：高速応答性を有する気体用層流型流量計の 特性解析, 計測自動制御学会論文集, 33-1, 1/6 (1997)

|

\section{[著 者 紹 介]}

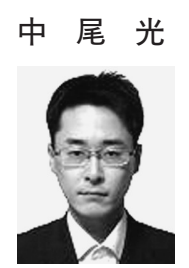

2008 年東京工業大学大学院総合理工学研究科 メカノマイクロ工学専攻博士前期課程修了. 同年 同専攻博士後期課程に入学し, 現在に至る. 流体 計測に関する研究に従事. 日本フルードパワーシ ステム学会の学生会員.

\section{川 嶋 健 嗣（正会員）}

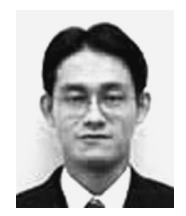

1992 年東京工業大学工学部制御工学科卒業. 97 年同大大学院理工学研究科制御工学専攻博士 後期課程修了. 同年東京都立工業高等専門学校機 械工学科助手, 2000 年東京工業大学精密工学研 究所助教授となり，現在同准教授。博士 (工学). 流体計測制御，ロボット工学に関する研究に従 事. 日本機械学会, 日本ロボット学会などの会 員.

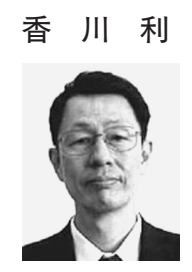

（正会員）

1974 年東京工業大学制御工学科卒業. 同年北 辰電機製作所入社, 76 年東京工業大学助手, 講 師, 助教授を経て, 現在精密工学研究所工教授。 圧縮性流体システム，流体計測，生体計測に関す る研究に従事. 工学博士. 日本フルードパワーシ ステム学会, 日本機械学会, 日本シミュレーショ ン学会などの会員. 